\title{
Nutrient limitations to bacterial and fungal growth during cellulose decomposition in tropical forest soils
}

\author{
Andrew T. Nottingham ${ }^{1,2}$ (D) - Lettice C. Hicks ${ }^{1,3}$ - Adan J. Q. Ceahuana ${ }^{4}$. \\ Norma Salinas $^{5}$ • Erland Bååth ${ }^{3}$ • Patrick Meir ${ }^{1,6}$
}

Received: 27 June 2017 /Revised: 20 September 2017 / Accepted: 2 October 2017 /Published online: 8 November 2017

(C) The Author(s) 2017. This article is an open access publication

\begin{abstract}
Nutrients constrain the soil carbon cycle in tropical forests, but we lack knowledge on how these constraints vary within the soil microbial community. Here, we used in situ fertilization in a montane tropical forest and in two lowland tropical forests on contrasting soil types to test the principal hypothesis that there are different nutrient constraints to different groups of microorganisms during the decomposition of cellulose. We also tested the hypotheses that decomposers shift from nitrogen to phosphorus constraints from montane to lowland forests, respectively, and are further constrained by potassium and sodium deficiency in the western Amazon. Cellulose and nutrients (nitrogen, phosphorus, potassium, sodium, and combined) were added to soils in situ, and microbial growth on cellulose (phospholipid fatty acids and ergosterol) and respiration were measured. Microbial growth on
\end{abstract}

Electronic supplementary material The online version of this article (https://doi.org/10.1007/s00374-017-1247-4) contains supplementary material, which is available to authorized users.

Andrew T. Nottingham

anotting@staffmail.ed.ac.uk

1 School of Geosciences, University of Edinburgh, Crew Building, Kings Buildings, Edinburgh EH9 3FF, UK

2 Smithsonian Tropical Research Institute, Apartado 0843-03092, Balboa, Ancon, Republic of Panama

3 Microbial Ecology, Department of Biology, Lund University, Ecology Building, SE-223 62 Lund, Sweden

4 Facultad de Ciencias Biologicas, Universidad Nacional de San Antonio Abad, Cusco, Peru

5 Seccion Química, Pontificia Universidad Católica del Peru, Lima, Peru

6 Research School of Biology, Australian National University, Canberra, ACT 0200, Australia cellulose after single nutrient additions was highest following nitrogen addition for fungi, suggesting nitrogen as the primary limiting nutrient for cellulose decomposition. This was observed at all sites, with no clear shift in nutrient constraints to decomposition between lowland and montane sites. We also observed positive respiration and fungal growth responses to sodium and potassium addition at one of the lowland sites. However, when phosphorus was added, and especially when added in combination with other nutrients, bacterial growth was highest, suggesting that bacteria out-compete fungi for nitrogen where phosphorus is abundant. In summary, nitrogen constrains fungal growth and cellulose decomposition in both lowland and montane tropical forest soils, but additional nutrients may also be of critical importance in determining the balance between fungal and bacterial decomposition of cellulose.

Keywords Decomposition · Ecological stoichiometry · Phospholipid fatty acids · Tropical lowland forest · Tropical montane forest $\cdot$ Soil carbon $\cdot$ Soil microorganisms

\section{Introduction}

The terrestrial carbon (C) cycle is regulated by the supply and demand of several crucial elements within organisms. The study of these elemental constraints has been framed within theories of ecological stoichiometry, which identify particularly important 'limiting nutrients' for growth or metabolism (Sterner and Elser 2002; von Liebig 1855) and have advanced our understanding of primary production and decomposition in global ecosystems (Elser et al. 2009, Zechmeister-Boltenstern et al. 2015). The application of this theory to soil processes, mediated by large and diverse communities of microorganisms, has often yielded results that are difficult to generalize (Chen et al. 2015; 
Kaspari et al. 2008; Waring 2012), and this raises the question of whether a single nutrient may limit processes within diverse microbial species assemblages (Danger et al. 2008).

The multiple nutrient constraints to belowground processes in tropical forests, such as decomposition and respiration, are particularly poorly understood. Fertilization and decomposition experiments have shown that phosphorus $(\mathrm{P})$, nitrogen $(\mathrm{N})$, sodium $(\mathrm{Na})$ and potassium $(\mathrm{K})$ all may limit soil microbial processes to some extent (Kaspari et al. 2008, 2009; Waring 2012). It remains unclear whether these variable responses to nutrient addition reflect different nutrient constraints to different groups of belowground organisms, different nutrient constraints to the decomposition of different organic matter substrates and/ or different environmental drivers of decomposition among sites. This problem is particularly challenging given our lack of understanding of whether and how different soil organisms regulate soil processes in general (Fierer 2017).

The $\mathrm{C}$ cycle in lowland tropical forests growing on strongly weathered soils is generally considered to be constrained by a deficiency of rock-derived P (Vitousek 1984). In contrast, the $\mathrm{C}$ cycle in montane tropical forests, where soils are the product of more recent tectonic uplift and erosion, is considered to be limited by $\mathrm{N}$, which slowly accumulates through biological fixation (Bruijnzeel et al. 2011; Tanner et al. 1992). This lowland-upland model, analogous to the Walker and Syers (1976) model of soil development, has received some support, but it is far from conclusive. For example, in different lowland tropical forests, $\mathrm{P}$ addition accelerated rates of decomposition (Kaspari et al. 2008) and microbial growth (Fanin et al. 2015; Turner and Wright 2014). In contrast, N limitation in tropical montane forest soils has been indicated by low concentrations of exchangeable N (Teh et al. 2013; Wolf et al. 2011) and increased soil $\mathrm{CO}_{2}$ efflux or microbial biomass following $\mathrm{N}$ fertilization (Cusack et al. 2011b; Fisher et al. 2013). In a study that included the same tropical forest sites as in this paper, a shift from $\mathrm{P}$ to $\mathrm{N}$ constraints to microbial growth with increased elevation was inferred by differences in the stoichiometry of N/P-degrading enzymes (Nottingham et al. 2015b). However, in many of these tropical forest sites, strong colimitation of $\mathrm{N}$ and $\mathrm{P}$ together has been demonstrated (Barantal et al. 2012; Fanin et al. 2012; Kaspari et al. 2008) and additional influences of another rock-derived nutrient, $\mathrm{K}$ has been identified (Kaspari et al. 2008). In the western Amazon, where oceanic $\mathrm{Na}$ deposition is low, there is also evidence that Na may limit heterotrophic metabolism, including fungi (Kaspari et al. 2009). Therefore, while there is evidence to support $\mathrm{P}$ and $\mathrm{N}$ limitation of soil microbial processes in lowland and montane forests, respectively, the roles of other nutrients remain unclear, and it is uncertain whether the underlying paradigm applies to widely varying underlying soils (Quesada et al. 2010).

One explanation for the apparent co-limitation of the soil C cycle by multiple nutrients in tropical forests (Kaspari et al.
2008) is that different communities of microorganisms may have different nutrient demands. For example, findings from soils in temperate systems have indicated that fungi and bacteria may respond differently to substrate and nutrient availability (Rousk and Bååth 2007) and, across a range of ecosystems, there were higher $\mathrm{C} / \mathrm{N}$ ratios in fungi compared to bacteria (Strickland and Rousk 2010). The overall nutrient constraint on decomposition in tropical forests may therefore be the consequence of complex interactions among different groups of microorganisms, competing for different nutrients. Other environmental factors differing between sites, like $\mathrm{pH}$, may also affect the fungal-to-bacterial balance during decomposition (Rousk et al. 2009).

In this study, we addressed the following questions: do different nutrients limit cellulose decomposition in montane and lowland tropical forest sites, and are fungi or bacteria the main decomposers of cellulose under different nutrient availabilities? Our experimental objective was to control the abundance of $\mathrm{C}$ and other nutrients added to soil; therefore, we added a cellulose $\mathrm{C}$-substrate in combination with different nutrients. We used cellulose because it is the most abundant organic polymer in plant biomass. This approach allowed us to accurately determine microbial growth on cellulose by using phospholipid fatty acid (PLFA) biomarkers, which were not present in our cellulose substrate but are present in natural leaf substrates. We measured the effect of fertilization (by N, P, K, Na and NPKNa together) on net respiratory $\mathrm{CO}_{2}$ effluxes from soil and on the microbial biomass increase on cellulose substrate. We performed these measurements in one montane tropical forest and two lowland tropical forests in southern Peru. The specific hypotheses we tested were as follows:

1) Microbial growth and respiration during cellulose decomposition are constrained primarily by $\mathrm{N}$ availability in montane forests and $\mathrm{P}$ availability in lowland forests.

2) The above pattern results, in part, from predominant $\mathrm{N}$ constraints to fungal decomposers (relatively more abundant in montane forest soils) and P constraints to bacterial decomposers (relatively more abundant in lowland forest soils).

3) $\mathrm{K}$ and $\mathrm{Na}$ act as additional constraints to soil microbial respiration and growth in lowland Amazon forest.

\section{Methods and materials}

\section{Study sites}

The experiment was performed at three sites situated in the Peruvian Andes-Amazon corridor: one site in tropical 
montane cloud forest (WAY) and two sites in lowland tropical forest sites on contrasting soils (TAM-05 and TAM-06; Table 1). The sites are located at 3025, 210 and $194 \mathrm{~m}$ above sea level and are situated along an elevation gradient on the Eastern flank of the Peruvian Andes with approximately $230 \mathrm{~km}$ separating the upper and lower sites. Site WAY is situated in the Estación Biologica de Wayqecha on the eastern slope of the Andes, in the Cusco region. Sites TAM-05 and TAM-06 are situated in the Tambopata reserve, in the Madre de Dios region. Mean annual temperature is 11.1, 26.4 and $26.4{ }^{\circ} \mathrm{C}$, mean annual precipitation is 1706,3199 and $2730 \mathrm{~mm}$ year $^{-1}$, respectively. Although mean annual precipitation is lower for WAY, the soils are rarely moisture-limited over the seasonal cycle partly due to occult precipitation and limited evapotranspiration (van de Weg et al. 2009, 2014; Zimmermann et al. 2010). All sites are under closed canopy forest with relatively homogeneous stand structure, topography and minimal signs of human interference. The dominant tree families in the montane site are Clusiaceae and Cunoniceae and in the lowland sites are Moraceae and Fabaceae. The sites are situated on Palaeozoic metasedimentary mudstones (WAY) $(\sim 450 \mathrm{Ma})$, a Pleistocene alluvial terrace (TAM-05; < $100 \mathrm{Ka}$ ) and a Holocene alluvial terrace (TAM-06; < $10 \mathrm{Ka}$ ), and the soils have been classified as Umbrisol (Umbrepts), Haplic Cambisol (Inceptisol) and Haplic Alisol (Ultisol) (according to FAO, with USDA Soil Taxonomy in parentheses; Quesada et al. 2010). The soil profile to bedrock at higher elevations is relatively shallow but has a deeper organic layer than at lower elevations (e.g. $22.8 \mathrm{~cm}$ organic layer at WAY compared to $0.7 \mathrm{~cm}$ at TAM06). Soil at WAY contains higher $\mathrm{C}, \mathrm{N}$ and $\mathrm{P}$ concentrations than at TAM-05 and TAM-06. The difference in age and degree of weathering between the two lowland sites is reflected by lower total base content and lower total P for TAM-05 compared to TAM-06. (273 vs. $978 \mathrm{mmol} \mathrm{c} \mathrm{kg}^{-1}$ and 256 vs. $529 \mathrm{mg} \mathrm{P} \mathrm{kg}^{-1}$ ) (Malhi et al. 2014). Further descriptions of soil properties (Quesada et al. 2010; Whitaker et al. 2014; Zimmermann et al. 2009), climate (Rapp and Silman 2012) and aboveground productivity and floristic composition (Asner et al. 2013; Feeley et al. 2011; Girardin et al. 2010) for these sites are reported elsewhere.

\section{Experimental design}

We conducted a partially factorial cellulose decomposition and fertilization experiment at each site, with the following treatments: cellulose, cellulose and $\mathrm{N}$ (cellulose $+\mathrm{N})$, cellulose and $\mathrm{P}$ (cellulose $+\mathrm{P})$, cellulose and $\mathrm{K}$ (cellulose $+\mathrm{K}$ ), cellulose and $\mathrm{Na}$ (cellulose $+\mathrm{Na}$ ), cellulose and combined nutrients (cellulose + Tot), combined nutrients (Tot) and no addition controls (NoAd), each with four replicates. Cellulose was added using cellulose filter papers (grade 1; GE Whatman, UK), cut into $2 \mathrm{~cm}^{2}$ pieces and weighed $(24 \mathrm{~g}$ dry weight; $10 \mathrm{~g} \mathrm{C}$ ) into nylon mesh bags measuring $15 \mathrm{~cm}^{2}$ (1 mm diameter mesh). Nutrients were added in $10 \mathrm{ml}$ solutions for $\mathrm{N}\left(\mathrm{NH}_{4} \mathrm{NO}_{3}\right), \mathrm{P}\left(\mathrm{Na}_{2} \mathrm{HPO}_{4}\right), \mathrm{K}(\mathrm{KCl}), \mathrm{Na}(\mathrm{NaCl})$ or in combination. The daily additions were approximately 0.2 g element day ${ }^{-1}$, to maintain microbial elemental ratios approximately within published ranges $(\mathrm{C} / \mathrm{N} / \mathrm{P} / \mathrm{K} / \mathrm{Na}$ of 60:7:1:1:1; $\mathrm{C}$ in added cellulose and $\mathrm{N}, \mathrm{P}, \mathrm{K}, \mathrm{Na}$ in added nutrient solutions) (Cleveland and Liptzin 2007). Elements were added slightly in excess, assuming losses due to leaching and sorption, and assuming parity of $\mathrm{P}, \mathrm{Na}$ and $\mathrm{K}$ ratios. For cellulose-only and controls (NoAd), we added $10 \mathrm{ml}$ of water instead of the treatment solution.

The plots at each of the three sites measured approximately $260 \mathrm{~m}^{2}$ and consisted of a grid of 32 soil collars $(10 \mathrm{~cm}$ deep, $20 \mathrm{~cm}$ diameter PVC tubes inserted to $3 \mathrm{~cm}$ soil depth), each separated by approximately $3 \mathrm{~m}$. The individual soil collars were spaced sufficiently far apart to ensure there was no

Table 1 Summary of site characteristics along the elevation gradient

\begin{tabular}{llll}
\hline Site code & WAY & TAM-05 & TAM-06 \\
\hline Site name & Wayqecha & Tambopata 5 & Tambopata 6 \\
Elevation (m asl) & 3025 & 210 & 194 \\
Co-ordinates (lat., long.) & $-13.190,-71.587$ & $-12.830,-69.271$ & $-12.839,-69.296$ \\
Mean annual temperature $\left({ }^{\circ} \mathrm{C}\right)$ & 11.1 & 26.4 & 26.4 \\
Annual precipitation $\left(\mathrm{mm}_{\text {year }}{ }^{-1}\right)$ & 1706 & 3199 & 2730 \\
Parent material & Palaeozoic shales-slates & Pleistocene alluvial terrace & Holocene alluvial terrace \\
Soil classification & Umbrisol & Haplic Cambisol & Haplic Alisol \\
Soil organic horizon $(\mathrm{cm})$ & 23 & 2 & 1 \\
Total C $(\%)$ org/min & $46.5 / 14.6$ & $5.5 / 1.7$ & $13.8 / 2.4$ \\
Total N $(\%)$ org/min & $2.4 / 0.9$ & $0.37 / 0.23$ & $1.00 / 0.35$ \\
Total P $\left(\mathrm{mg} \mathrm{g}{ }^{-1}\right.$ ) org $/ \mathrm{min}$ & $1.09 / 1.32$ & $0.28 / 0.18$ & $0.76 / 0.49$ \\
Soil $\mathrm{pH}$ & $4.1 / 4.1$ & $3.8 / 3.7$ & $5.4 / 4.6$ \\
\hline
\end{tabular}

Soil properties are means of five spatial replicates, for organic horizon and mineral horizons (org/min) 
interaction (e.g. nutrient run-off) and were, therefore, independent analytical replicates ( $n=4$ per site). The plots were situated next to long-term 1 ha permanent sampling plots (Nottingham et al. 2015a). Because soil biological and physicochemical properties within the 1 ha plots have relatively minor variation compared to among the 1 ha plots (Whitaker et al. 2014), our experimental plots accurately represented variability in soil characteristics at each site and provided ecologically meaningful comparisons between sites. The collars were placed in the soil at least 2 weeks prior to the experiment. Treatments were stratified based on soil $\mathrm{CO}_{2}$ efflux measurements made on the first day of the experiment, and treatments began at the end of the first day. Stratification was performed by grouping 32 soil collars into 4 groups $\left(\mathrm{CO}_{2}\right.$ efflux level: 'lowest', 'low', 'high', 'highest') and then randomly assigning a treatment to one collar for each group. Cellulose mesh bags were carefully placed in contact with the soil surface inside each of the $20 \mathrm{~cm}$ diameter soil collars, following removal of the leaf-litter standing crop. Thus, the added cellulose was the only C-substrate present within each soil collar. Nutrient solutions or water were added evenly to each of the mesh bags at the end of soil $\mathrm{CO}_{2}$ efflux measurements for each day, therefore maintaining nutrient supply to microbial communities throughout the experiment. The experiment periods were as follows: 20 days (WAY), 16 days (TAM-05) and 11 days (TAM-06). The length of the experiment varied slightly for each site, partly intentionally (longer in the cloud forest because of slower decomposition rates) and partly because of logistical constraints and access to field sites. However, these differences did not restrict testing our hypotheses and did not affect our main conclusions, which are based on the relative differences in microbial growth and C-turnover with/without nutrient additions for each site (and not based on the absolute quantities of $\mathrm{C}$ decomposed or respired). Neither did these differences influence our microbial growth results: because we used a cellulose-only substrate, our results were not confounded by the successional changes in microbial communities that can occur during the decomposition of more complex lignocellulolytic substrates. Mesh bags containing cellulose for determination of microbial biomass (see below) and decomposition were collected following the final set of soil $\mathrm{CO}_{2}$ efflux measurements for each site. However, the short-term nature of the experiment resulted in low rates of mass loss (ranging between 5 and 10\%), not allowing for discrimination between treatments, and these data are therefore not reported. Increases in microbial biomass (PLFA and ergosterol) and $\mathrm{CO}_{2}$ efflux were instead used as indicators of soil $\mathrm{C}$-cycle dynamics ( $\mathrm{C}$ degraded and respired).

\section{Soil $\mathrm{CO}_{2}$ efflux}

Soil $\mathrm{CO}_{2}$ efflux was determined using an infrared gas analyser connected to a $20-\mathrm{cm}$ diameter survey chamber (LI-COR
Biosciences, UK). Soil $\mathrm{CO}_{2}$ efflux was measured above the mesh bags. Mesh bags were not moved during the experiment and microbial growth on the cellulose was not disturbed. For analyses of site and treatment effects on $\mathrm{CO}_{2}$ efflux, we used the average rate of $\mathrm{CO}_{2}$ efflux determined during the first 11 days following treatments (in $\mathrm{g} \mathrm{CO}_{2}-\mathrm{C} \mathrm{m}^{-2}$ day $^{-1}$ ); therefore, allowing evaluation of treatment effects among sites with variable measurement periods.

\section{Phospholipid fatty acid and ergosterol analysis}

During the experimental period, the cellulose was colonized by decomposer microorganisms, and the increase in microbial biomass on the cellulose was taken to be equivalent to cumulative microbial growth, i.e. microbial growth during decomposition integrated over the entire experimental period. We used phospholipid fatty acids (PLFAs) to quantify microbial biomass, which also give a relative index of fungal-tobacterial biomass. Extraction and determination of PLFAs followed Frostegård and Bååth (1993), using $3 \mathrm{~g}$ frozen cellulose (rapidly thawed before weighing) from each replicate. An internal standard (methyl nonadecanoate 19:0) was added before the methylation step. For each sample, the relative abundance of individual fatty acids was estimated as the proportion of the sum of all PLFAs (mol\%), subsequently used in a principal component analysis (PCA). The mole percentage values were standardized to unit variance before subjecting the data to the PCA. We used the 21 most common PLFAs in the PCA (Table S1). The sum of the 21 PLFAs relative to the internal standard was also used as a relative measure of total biomass (totPLFA). The PLFA a15:0, which is widely found in Gram+ bacteria from the genus Cellulomonas (Lednická et al. 2000; Minnikin et al. 1979), was used as an indicator for cellulose-decomposing bacteria. The PLFA 18:2 $\omega 6,9$ was used as an indicator for fungal biomass, with that of 18:1 $\omega 9$ as additional evidence of fungal origin, although it is not a perfect indicator of fungi (Frostegård et al. 2011). Ergosterol was measured as an alternative fungal biomass indicator, following Rousk and Bååth (2007). Due to a lack of experimental material, this analysis was only made on three replicates per treatment. Our statistical power was increased by comparing two independent indicators of fungal growth (PLFA and ergosterol).

\section{Statistical analyses}

To test for overall site, treatment and interacting effects, we used two-way ANOVA, with 'site' and 'treatment' as factors and the measured parameter as the response variable. To test for treatment effects for each site, we used one-way ANOVA, with treatment as the factor and the measured parameter as the response variable, followed by Dunnett's post-hoc tests between control and treatment pairs. To further distinguish between the effects of nutrient addition on respiration, we 
Table 2 The overall effects of site and fertilization (two-way ANOVA) on $\mathrm{CO}_{2}$ efflux

\begin{tabular}{lrrrc}
\hline & \multicolumn{4}{l}{$\mathrm{CO}_{2}$ efflux } \\
\cline { 2 - 5 } & df & $\mathrm{SS}$ & \multicolumn{1}{l}{$F$} & \multicolumn{1}{c}{$p$} \\
\hline Site & 2 & 8145 & 15.6 & $<0.001^{* * *}$ \\
Fertilization & 7 & 5216 & 2.9 & $0.011^{*}$ \\
Site * Fertilization & 14 & 7231 & 2.0 & $0.031^{*}$ \\
\hline
\end{tabular}

The significant effects of specific nutrients for each site (Dunnett's test) are highlighted in Fig. 1

Significant effects are highlighted by asterisks where $* \mathrm{P} \leq 0.05$, ** $\mathrm{P} \leq 0.01, * * * \mathrm{P} \leq 0.001$

performed post-hoc tests where 'controls' were soil-only no addition controls (NoAd) (i.e. effect of cellulose and nutrient addition compared to no addition) and cellulose-only controls (cellulose) (i.e. effect of cellulose and nutrient addition compared to cellulose addition). Significant differences were determined at $P \leq 0.05$. All statistical analyses were performed in $\mathrm{R}$ (version 3.1.1).

\section{Results}

Soil $\mathrm{CO}_{2}$ efflux differed among treatments and sites (site $P<0.001$, Treatment $P=0.011$, Site * Treatment $P=0.031$ ) (Table 2; Fig. 1). The lowland sites had the highest rates of soil $\mathrm{CO}_{2}$ efflux, e.g. control soil $\mathrm{CO}_{2}$ efflux was $39 \%$ higher in TAM-06 compared to WAY. Adding cellulose alone increased soil $\mathrm{CO}_{2}$ efflux. For example, during the first 11 days in WAY, it doubled, while adding nutrients without cellulose (treatment Tot) did not increase soil $\mathrm{CO}_{2}$ efflux. This indicated

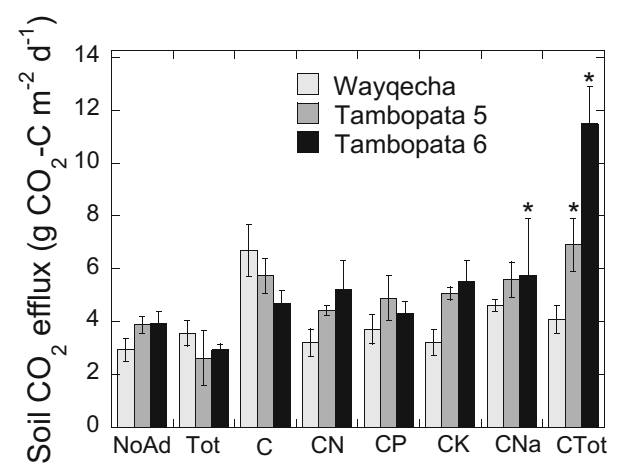

Fig. 1 The response of soil $\mathrm{CO}_{2}$ efflux to cellulose and nutrient addition treatments at montane (WAY) and lowland (TAM-05 and TAM-06) tropical forest sites. Soil $\mathrm{CO}_{2}$ efflux is the average rate of $\mathrm{CO}_{2}$ efflux determined during the first 11 days following treatments (in $\mathrm{g} \mathrm{CO}_{2}$ $\mathrm{C} \mathrm{m}^{-2}$ day $^{-1}$ ). Treatments are as follows: NoAd $=$ no addition controls, Tot $=$ nutrients only, $\mathrm{C}=$ cellulose only controls, $\mathrm{CN}=$ cellulose with $\mathrm{N}$, $\mathrm{CP}=$ cellulose with $\mathrm{P}, \mathrm{CK}=$ cellulose with $\mathrm{K}, \mathrm{CNa}=$ cellulose with $\mathrm{Na}$, CTot $=$ cellulose with all nutrients combined. Significant differences between treatments and 'NoAd' controls (Dunnett's tests) within sites are shown where $p<0.05$. Error bars represent one standard error $(n=4)$ that $\mathrm{C}$ was the primary limiting resource for soil microbial activity. Adding cellulose together with all nutrients (treatment cellulose + Tot) increased soil $\mathrm{CO}_{2}$ efflux further in the lowland sites: 50 and 20\% higher following cellulose addition and 180 and $290 \%$ higher following cellulose + Tot addition for TAM-05 and TAM-06, respectively. Soil $\mathrm{CO}_{2}$ efflux measurements were, however, too variable to clearly detect the effects of specific nutrients when added with cellulose relative to cellulose addition alone, although there was significantly higher soil $\mathrm{CO}_{2}$ efflux relative to controls in TAM-05 following the addition of cellulose with $\mathrm{N}+\mathrm{P}+\mathrm{K}+\mathrm{Na}$ (cellulose + Tot) and in TAM-06 following addition of cellulose with $\mathrm{Na}$ and with $\mathrm{N}+\mathrm{P}+\mathrm{K}+\mathrm{Na}(P<0.05)$.

The microbial community composition, estimated by the PLFA distribution, differed among sites, with the largest differences between WAY and the two lowland sites

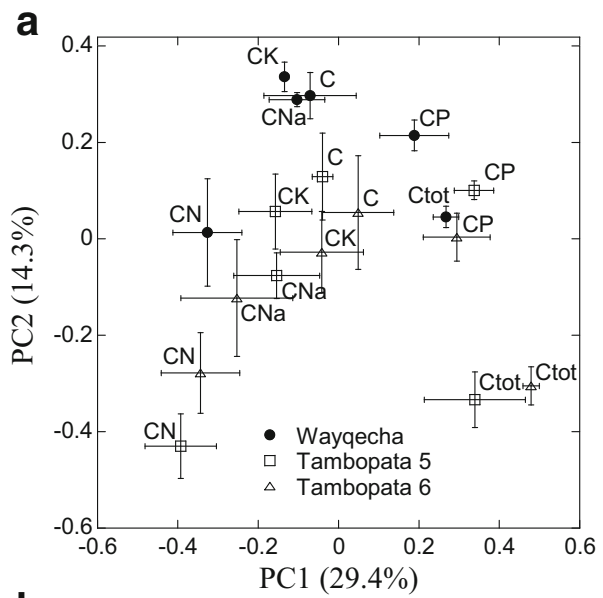

b

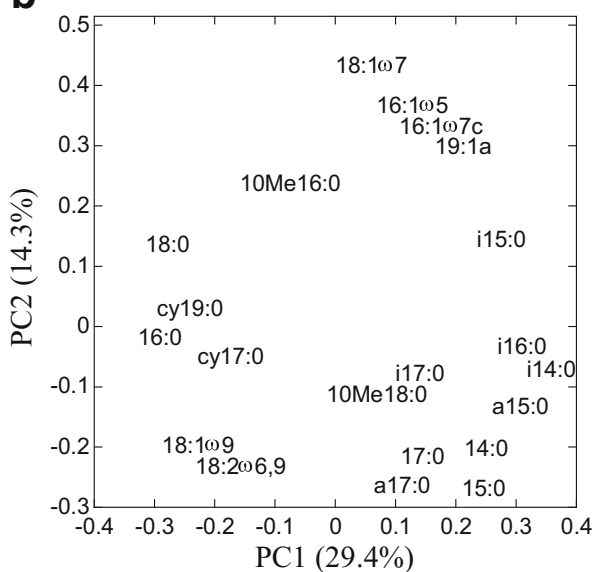

Fig. 2 Microbial community composition on cellulose at montane (WAY) and lowland (TAM-05 and TAM-06) tropical forest sites in response to fertilization, according to a principal component analysis of the PLFA pattern expressed as mole percentage. a Scores of the different sites and treatments, with treatments differentiating along PC1 and sites along PC2. Variation explained by each component is given within parenthesis. Treatments are as follows: $\mathrm{C}=$ cellulose only controls, $\mathrm{CN}=$ cellulose with $\mathrm{N}, \mathrm{CP}=$ cellulose with $\mathrm{P}, \mathrm{CK}=$ cellulose with $\mathrm{K}, \mathrm{CNa}=$ cellulose with $\mathrm{Na}, \mathrm{CTot}=$ cellulose with all nutrients combined. $\mathbf{b}$ Loadings of individual PLFAs. Error bars represent one standard error $(n=4)$ 
(differentiating along PC2 of the PLFA pattern, Fig. 2a; mol\% values for individual PLFAs are reported in Table S1). Despite these differences, the community composition shifted similarly among sites in response to fertilization along PC1. The PC1 scores averaged across all sites were significantly higher for cellulose $+\mathrm{P}$ and cellulose + Tot treatments compared to cellulose only $(P<0.01)$ and significantly lower (negative PC1 score) for cellulose $+\mathrm{N}$ treatments compared to cellulose only $(P<0.01)$ (Fig. 2a). There were no significant differences in $\mathrm{PC} 1$ scores following cellulose $+\mathrm{Na}$ and cellulose $+\mathrm{K}$ compared to cellulose only treatments, although cellulose $+\mathrm{Na}$ treatments had more negative scores relative to cellulose only for the lowland sites (TAM-05 and TAM-06). The separation along PC1 corresponded to negative PC1 loadings for fungal biomarkers $(18: 2 \omega 6,9,18: 1 \omega 9)$ and positive PC1 loadings for bacterial biomarkers (a15:0, i14:0 i15:0 i16:0) (Fig. 2b), suggesting that fungi dominated cellulose decomposition after $\mathrm{N}$-addition, whereas bacteria dominated the $\mathrm{P}$ and $\mathrm{N}+\mathrm{P}+\mathrm{K}+$ Na-addition (cellulose + Tot) responses.

Considering the biomass indices of specific microbial groups, there were effects of both site and treatments on total PLFA, as well as fungal and bacterial biomarkers, but the effect differed for different nutrients (Fig. 3; Table 3). Total PLFA only increased significantly for the cellulose + Tot treatment (Fig. 3a). More information was present, however, if specific groups were studied. For bacteria, $\mathrm{N}+\mathrm{P}+\mathrm{K}+\mathrm{Na}-$ addition to cellulose (cellulose + Tot) led to a large significant increase $(P<0.001)$ in PLFA concentration (bacterial biomarker a15:0) in all sites, with a smaller, but significant, response to only $\mathrm{P}$ addition $(P=0.03)$ and an even smaller response to $\mathrm{K}$ addition in TAM-06 (cellulose $+\mathrm{P}$ and cellulose $+\mathrm{K}$ in Fig. 3b). For fungi, in contrast, the addition of $\mathrm{N}+\mathrm{P}+$ $\mathrm{K}+\mathrm{Na}$ or $\mathrm{N}$ led to significant increases $(P<0.01)$ in PLFA

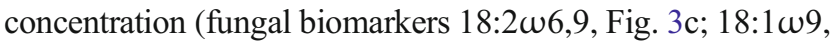
data not shown) in all sites, with further smaller responses to $\mathrm{K}$ and $\mathrm{Na}$ addition in TAM-06 (see cellulose + Tot, cellulose $+\mathrm{N}$ cellulose $+\mathrm{K}$, cellulose $+\mathrm{Na}$ in Fig. 3c). The patterns for fungal PLFA biomarkers were consistent with the ergosterol content, with large effects of cellulose + Tot and cellulose $+\mathrm{N}$ treatments in all sites $(P<0.05)$ and small effects of cellulose $+\mathrm{Na}$ and cellulose $+\mathrm{K}$ treatments at one site, TAM-06 (Fig. 4). The different growth responses of bacteria and fungi to nutrient additions were reflected by different log cellulose + $\mathrm{N} /$ cellulose $+\mathrm{P}(\mathrm{CN} / \mathrm{CP}) \mathrm{PLFA}$ response ratios: the response of bacteria (PLFA a15:0) was negative, while the response of

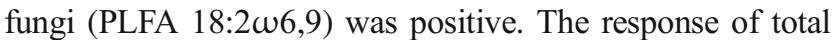
PLFA was not significantly different to zero (Fig. 3d).

\section{Discussion}

In this study, we tested whether microbial $\mathrm{C}$ metabolism during cellulose degradation was predominantly constrained by $\mathrm{P}$ and
$\mathrm{N}$ availability in lowland and montane tropical forests, respectively (hypothesis 1) (Cusack et al. 2011a; Turner and Wright 2014), and whether these patterns can partly be explained by different nutrient constraints to bacterial and fungal growth (hypothesis 2 ). However, contrary to hypothesis 1 , similar biomass increases in fungal growth (Figs. 3c and 4) and changes in community composition (Fig. 2) were found for the montane (WAY) and lowland (TAM-05 and TAM-06) sites when adding $\mathrm{N}$, suggesting that when $\mathrm{C}$ limitation was alleviated by adding cellulose, $\mathrm{N}$ became the main limiting nutrient in all sites.

The greatest shifts in microbial community composition after additions of single nutrients occurred following $\mathrm{N}$ and $\mathrm{P}$ addition (Fig. 2a), whereby $\mathrm{N}$ addition was associated with fungal dominance and $\mathrm{P}$ addition was associated with bacterial dominance (Figs. $2 \mathrm{~b}$ and $3 \mathrm{~b}-\mathrm{d}$ ). This result supported our second hypothesis and, when examined alongside evidence for fungal dominance of the microbial community at higher elevation (Traunspurger et al. 2017; Whitaker et al. 2014), provided a degree of indirect support for our first hypothesis of a more $\mathrm{N}$-constrained fungal-dominated community at higher elevation. This hypothesis was also indirectly supported by a previous study of enzymatic stoichiometry in the same sites, which showed an increase in the ratio of $\mathrm{N}$ - to $\mathrm{P}$ degrading soil enzyme activities with increased elevation (Nottingham et al. 2015b). There are, therefore, independent sources of indirect evidence to support our first hypothesis, but we suggest that whether these patterns result in shifts in nutrient constraints to decomposition depends on the chemical composition of the added $\mathrm{C}$ substrate.

Fungal growth was consistently stimulated by $\mathrm{N}$ addition at all sites, which can be explained by the nature of cellulose substrate. The increase in fungal, and not bacterial growth, on cellulose after adding $\mathrm{N}$, has been observed elsewhere (Meidute et al. 2008), including in lowland tropical forest in French Guiana (Fanin et al. 2012). Cellulose-rich substrates, such as straw, have also been shown to favour fungal growth, which increased further after adding $\mathrm{N}$ (Henriksen and Breland 1999; Rousk and Bååth 2007). Thus, the increased fungal growth on cellulose with $\mathrm{N}$ addition might not be a function of $\mathrm{N}$ per se, but due to alleviating limitation for growth on a substrate already favouring fungal over bacterial growth. Alleviating $\mathrm{N}$ limitation after adding another $\mathrm{C}$ substrate favouring bacterial growth (e.g. glucose or starch) was shown to favour bacterial growth (Kamble and Bååth 2014; Meidute et al. 2008). Thus, the predominant fungal response to $\mathrm{N}$-addition in our study may be explained by the manner in which cellulose favours fungal growth rather than the extent to which fungi and bacteria have different $\mathrm{C} / \mathrm{N}$ ratios (de Ruiter et al. 1993; Six et al. 2006).

Surprisingly, bacteria were favoured by adding $\mathrm{P}$ and especially by adding all nutrients together. The PLFA that increased the most in these treatments (PLFAs a15:0, i14:0, i15:0, i16:0) are all commonly found in cellulolytic bacteria (Lednická et al. 

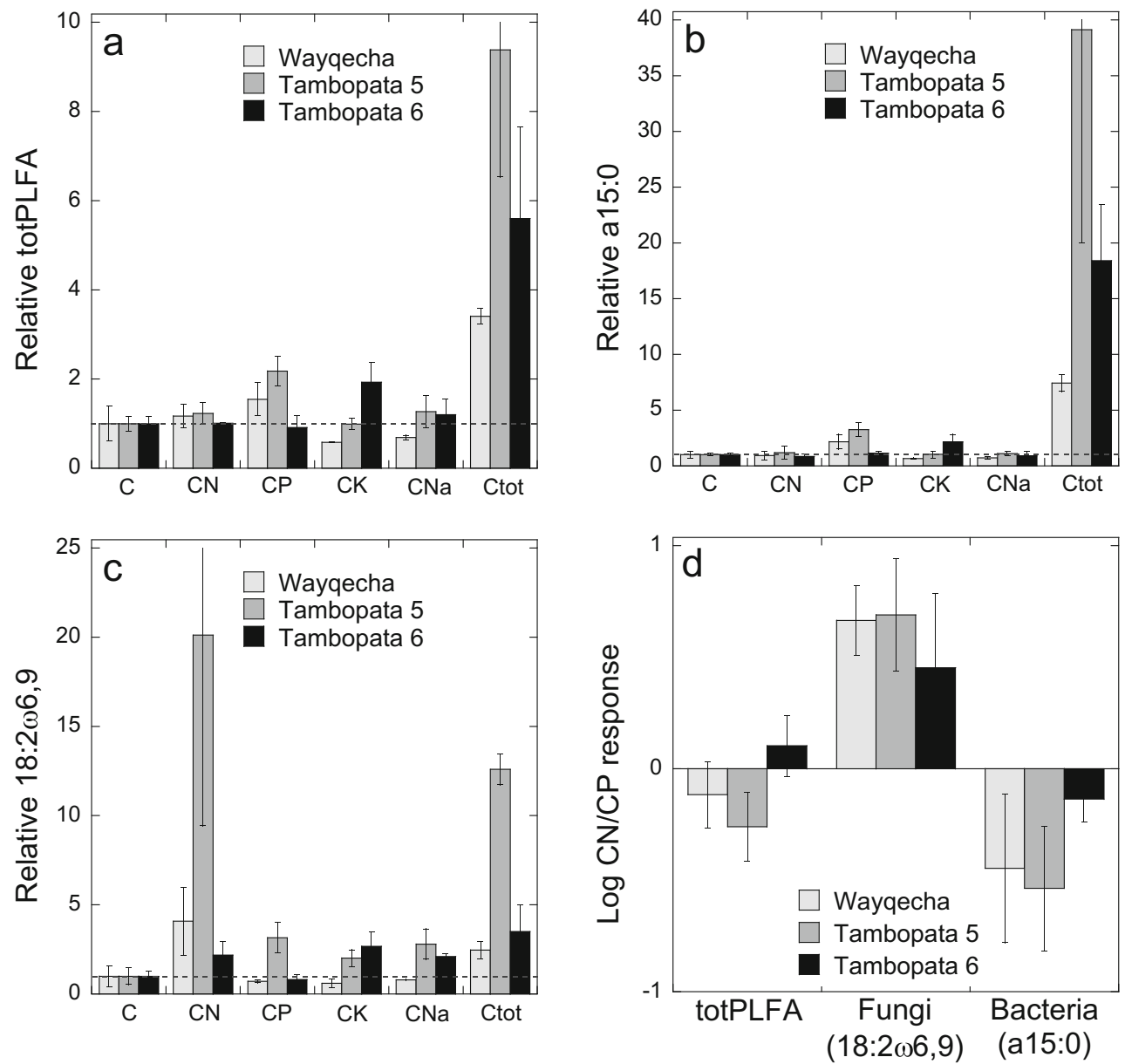

Fig. 3 The relative abundance of PLFAs on cellulose at montane (WAY) and lowland (TAM-05 and TAM-06) tropical forest sites in response to fertilization. a Total microbial biomass (totPLFA). b Bacterial biomarker a15:0. c Fungal biomarker 18:2w6,9. d Relative growth response of $\mathrm{N}$ (treatment $\mathrm{CN}$ ) compared to $\mathrm{P}$ addition $(\mathrm{CP})$ for total microbial biomass, bacteria and fungi. All values are relative responses, in $\mathbf{a}-\mathbf{c}$ relative to cellulose-only controls $(\mathrm{C}$, where control $=1$; indicated by dashed line). $\mathrm{CTot}=$ cellulose with all nutrients $(\mathrm{N}+\mathrm{P}+\mathrm{K}+\mathrm{Na})$ added. To determine

the relative response of cellulose $+\mathrm{N}$ and cellulose $+\mathrm{P}$ additions (d), we determined log response ratios for total microbial biomass, bacterial and fungal biomarkers following cellulose $+\mathrm{N}$ addition ( $\mathrm{CN}$ in figure) relative to following cellulose $+\mathrm{P}$ addition ( $\mathrm{CP}$ in figure). Positive values suggest $\mathrm{N}$ limitation to microbial growth on cellulose, while negative values suggest $\mathrm{P}$ limitation. PLFA concentrations for individual biomarkers are reported in Table S1. Error bars represent one standard error $(n=4)$

Table 3 The overall effects of site and fertilization (two-way ANOVA) and the effects of specific nutrients (Dunnett's test) on microbial growth estimated by phospholipid fatty acid (PLFA) concentration

\begin{tabular}{|c|c|c|c|c|c|c|c|c|c|c|c|c|c|c|c|c|c|}
\hline & & \multicolumn{4}{|c|}{ Total PLFA } & \multicolumn{4}{|c|}{ Fungi $(18: 2 \omega 6,9)$} & \multicolumn{4}{|c|}{ 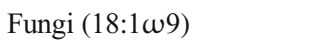 } & \multicolumn{4}{|c|}{ Bacteria (a15:0) } \\
\hline & & df & SS & $F$ & $p$ & df & SS & $F$ & $p$ & df & SS & $F$ & $p$ & df & SS & $F$ & $p$ \\
\hline \multirow{3}{*}{$\begin{array}{l}\text { Overall } \\
\text { effects }\end{array}$} & Site & 2 & 1.7 & 26.2 & $<0.001 * * *$ & 2 & 2.2 & 15.7 & $<0.001 * * *$ & 2 & 2.3 & 17.0 & $<0.001 * * *$ & 2 & 1.1 & 8.1 & $<0.001 * * *$ \\
\hline & Fertilization & 5 & 4.9 & 30.6 & $<0.001 * * *$ & 5 & 5.1 & 14.5 & $<0.001 * * *$ & 5 & 4.5 & 13.4 & $<0.001 * * *$ & 5 & 14.8 & 43.2 & $<0.001 * * *$ \\
\hline & $\begin{array}{l}\text { Site } * \\
\quad \text { Fertilization }\end{array}$ & 10 & 0.9 & 2.8 & $0.008^{* *}$ & 10 & 1.9 & 2.7 & $0.009 * *$ & 10 & 1.7 & 2.6 & $0.013^{* *}$ & 10 & 1.1 & 1.6 & 0.14 \\
\hline \multirow{5}{*}{$\begin{array}{l}\text { Nutrient } \\
\text { effects }\end{array}$} & $\mathrm{N}$ & & & & 0.78 & & & & $<0.001 * * *$ & & & & $<0.001 * * *$ & & & & 0.92 \\
\hline & $\mathrm{P}$ & & & & 0.11 & & & & 0.96 & & & & 0.93 & & & & $0.03 *$ \\
\hline & $\mathrm{K}$ & & & & 0.98 & & & & 0.29 & & & & 0.94 & & & & 0.99 \\
\hline & $\mathrm{Na}$ & & & & 1.00 & & & & 0.26 & & & & 0.40 & & & & 0.93 \\
\hline & Combined & & & & $<0.001 * * *$ & & & & $<0.001 * * *$ & & & & $<0.001 * * *$ & & & & $<0.001 * * *$ \\
\hline
\end{tabular}

Significant effects are highlighted by asterisks where $* \mathrm{P} \leq 0.05, * * \mathrm{P} \leq 0.01$, *** $\mathrm{P} \leq 0.001$ 


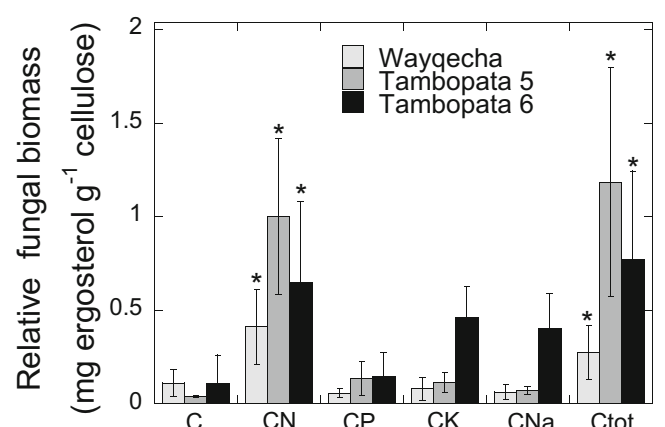

Fig. 4 Fungal growth (estimated by ergosterol concentration) on cellulose in response to fertilization, in montane (WAY) and lowland (TAM-05 and TAM-06) tropical forest sites. Treatments are either cellulose only $(\mathrm{C})$ or cellulose with nutrients $(\mathrm{CTot}=$ cellulose with all nutrients $(\mathrm{N}+\mathrm{P}+\mathrm{K}+\mathrm{Na})$ added). Significant differences relative to controls (Dunnett's tests) are highlighted by asterisks $(P<0.05)$. Error bars represent one standard error $(\mathrm{n}=3)$

2000; Minnikin et al. 1979), indicating that cellulose decomposition had switched from being mainly fungal to mainly bacterial in these two treatments. This result is supported by a controlled laboratory study of cellulose decomposition under fertilization in temperate soils, where low N:P supply ratios were associated with bacterial dominance and high $\mathrm{N}: \mathrm{P}$ supply ratios were associated with fungal dominance (Güsewell and Gessner 2009). Bacteria are known to have relatively low C/P ratios, compared to fungi, which may be related to their small size and large surface area to volume ratio, which increases the relative demand for P-rich membrane phospholipids (Kirchman 2008). These differences in nutritional requirements of bacteria and fungi may provide an explanation for our observations of fungi out-competing bacteria for added $\mathrm{N}$ under low $\mathrm{P}$ conditions, but bacteria out-competing fungi for added $\mathrm{N}$ under high $\mathrm{P}$ conditions (Fig. 3).

However, soil $\mathrm{pH}$ changes have been shown to have large differential effects on bacterial and fungal growth rates, where high $\mathrm{pH}$ favours bacterial growth and low $\mathrm{pH}$ favours fungal growth (Rousk et al. 2010). Therefore, our result of inhibited bacterial growth could also be a result of a lowered soil $\mathrm{pH}$ following $\mathrm{NH}_{4} \mathrm{NO}_{3}$ addition, which favoured fungal growth and especially higher $\mathrm{pH}$ following addition of $\mathrm{Na}_{2} \mathrm{HPO}_{3}$ favouring bacterial growth. To further investigate the effect of nutrient additions on $\mathrm{pH}$ under controlled conditions, we added nutrients and $\mathrm{H}_{2} \mathrm{O}$ to cellulose at the same ratios as the field experiment $\left(\mathrm{H}_{2} \mathrm{O}\right.$ additions were based on the average rainfall during the experiment period of $300 \mathrm{~mm}$, equivalent to approximately 4.71 of $\mathrm{H}_{2} \mathrm{O}$ per $24 \mathrm{~g}$ filter paper). The resulting $\mathrm{pH}$ changes (cellulose-only control $=7.0$, cellulose + $\mathrm{N}=7.0$, cellulose $+P=7.3$, cellulose $+\mathrm{K}=6.3$, cellulose + $\mathrm{Na}=6.2$, cellulose + Tot $=7.3$ ) supported an effect of $\mathrm{N}$ (rather than $\mathrm{pH}$ ) on fungal growth responses, but they do not rule out an interacting effect of $\mathrm{P}$ and $\mathrm{pH}$ on the bacterial growth responses. Thus, increased growth by bacteria on cellulose after adding P could be due to either P limitation or increased $\mathrm{pH}$ favouring bacterial growth. The extreme growth of bacteria and not fungi when all nutrients were added could then be explained by high $\mathrm{pH}$ favouring bacteria, inducing conditions where bacteria had a competitive advantage over fungi for added $\mathrm{N}$. To resolve this interaction, further experiments are required that independently control nutrients and $\mathrm{pH}$.

Several recent studies have shown that cations may be of considerable importance in constraining the soil food web in tropical forests (Kaspari et al. 2008, 2009; Waring 2012). Potassium constraints to decomposition may occur in lowland forests because $\mathrm{K}$, like $\mathrm{P}$, is primarily derived from bedrock and is lost during weathering (Kaspari et al. 2008). Here, our results were inconclusive because, although we observed positive effects of K-addition for fungal growth in a lowland site (TAM-06) and no effects in the montane site, there were no significant effects (Figs. 3 and 4).

The scarcity of ocean-derived $\mathrm{Na}$ in the Western Amazon has led to the hypothesis of $\mathrm{Na}$ limitation to decomposers in these ecosystems, especially to ants, termites and fungi (Kaspari et al. 2009). Consistent with this hypothesis, respiration positively responded to $\mathrm{Na}$ addition in our lowland site TAM-06 (Fig. 1). In the same site, TAM-06, we observed positive fungal growth responses to Na addition; although the individual effects were not significant, the trends were consistent for two independent measures (Figs. 3 and 4). This result could be confounded by the simultaneous addition of chloride $(\mathrm{Cl}$ in $\mathrm{NaCl})$, but there is little evidence to support $\mathrm{Cl}$ constraints on heterotrophic soil processes. For example, in another lowland forest in the Peruvian Amazon, the addition of $\mathrm{Na}$, but not $\mathrm{Cl}$, led to large increases in leaf litter decomposition and the abundance of soil macrofauna (Kaspari et al. 2009). In another western Amazon forest (in Yasuni, Ecuador), a year of $\mathrm{NaCl}$ fertilization led to a $70 \%$ increase in cellulose degradation which was associated with a 17-fold increase in termite abundance (Kaspari et al. 2014), but it is unlikely that termites accessed cellulose through the mesh used in our study (1 $\mathrm{mm}$ diameter). Thus, our results in a lowland Western Amazon tropical forest (TAM-06) tentatively suggest $\mathrm{Na}$ constraints to respiration associated with fungal growth (a component of the hypothesis of Kaspari et al. 2009), but longer-term studies are required to support this finding.

Our data also illustrate the variability among different lowland sites (TAM-05 compared to TAM-06), not only in Na constraints on respiration and fungal growth but also in how other nutrients constrain the growth of the entire microbial community (Fig. 3). The differences in nutrient constraints between the two lowland sites are likely due to geology, with TAM-06 situated on a floodplain where the input of nutrients in river sediments may sustain higher plant production (Asner et al. 2015). Heterogeneity of nutrient constraints in lowland forests may also arise through geographic variation in 
deposition (e.g. Na), or through geographic variation in the community composition of decomposers.

In summary, our results illustrate predominant $\mathrm{N}$ constraints on fungal growth and P-constraints on bacterial growth during cellulose decomposition in both lowland and montane tropical forest soils. These results suggest that the growth responses of specific microbial groups to different nutrients may underlie observations of the elemental stoichiometry of the microbial biomass as a whole (Cleveland and Liptzin 2007; Zhou et al. 2017). While our study mainly suggests $\mathrm{N}$ constraints to microbial growth on cellulose in both lowland and montane tropical forests, it also suggests possible $\mathrm{Na}$ and $\mathrm{K}$ constraints to fungal growth in some lowland tropical forest soils. Further research is required to test our findings using natural litter substrates, for longer time periods and where $\mathrm{pH}$ is controlled. Further research is also required to examine how nutrients affect the activity and synthesis of cellulases and $\beta$-glucosidases, the key enzymes produced by bacteria and fungi for cellulose degradation (Pathan et al. 2015). Our findings have implications for our understanding of how the soil microbial community may respond to perturbations in the global $\mathrm{C}$ and nutrient cycles and demonstrate the importance of looking beyond $\mathrm{C}-\mathrm{N}$ relationships in soil $\mathrm{C}$ cycle models.

Acknowledgements We thank the Asociacion para la Conservacion de la Cuenca Amazonica (ACCA) in Cusco and the Instituto Nacional de Recursos Naturales (INRENA) in Lima for access to the study sites. For their logistical support, we thank Dr. Eric Cosio and Eliana Esparza Ballón at Pontificia Universidad Católica del Perú (PUCP). For support in performing nutrient analyses, we thank Torstein Diem. For their support in the field, we thank Walter H. Huasco and Javier E. S. Espejo.

Funding information This study is a product of the Andes Biodiversity and Ecosystem Research Group consortium (www. andesconservation.org) and was financed by the UK Natural Environment Research Council NE/G018278/1 to PM, a European Union Marie-Curie Fellowship FP7-2012-329360 to ATN and ARC award DP170104091 to PM.

Open Access This article is distributed under the terms of the Creative Commons Attribution 4.0 International License (http:// creativecommons.org/licenses/by/4.0/), which permits unrestricted use, distribution, and reproduction in any medium, provided you give appropriate credit to the original author(s) and the source, provide a link to the Creative Commons license, and indicate if changes were made.

\section{References}

Asner GP, Anderson C, Martin RE, Knapp DE, Tupayachi R, KennedyBowdoin T, Sinca F, Malhi Y (2013) Landscape-scale changes in forest structure and functional traits along an Andes-to-Amazon elevation gradient. Biogeosci Discuss 10:15415-15454

Asner GP, Anderson CB, Martin RE, Tupayachi R, Knapp DE, Sinca F (2015) Landscape biogeochemistry reflected in shifting distributions of chemical traits in the Amazon forest canopy. Nat Geosci 8:567U114
Barantal S, Schimann H, Fromin N, Hattenschwiler S (2012) Nutrient and carbon limitation on decomposition in an Amazonian moist forest. Ecosystems 15:1039-1052

Bruijnzeel LA, Scatena FN, Hamilton LS (2011) Tropical montane cloud forests. Cambridge University Press, Cambridge

Chen Y, Sayer EJ, Li Z, Mo Q, Li Y, Ding Y, Wang J, Lu X, Tang J, Wang $F$ (2015) Nutrient limitation of woody debris decomposition in a tropical forest: contrasting effects of $\mathrm{N}$ and $\mathrm{P}$ addition. Funct Ecol 30:295-304

Cleveland CC, Liptzin D (2007) C:N:P stoichiometry in soil: is there a "Redfield ratio" for the microbial biomass? Biogeochemistry 85 : 235-252

Cusack DF, Silver WL, Torn MS, Burton SD, Firestone MK (2011a) Changes in microbial community characteristics and soil organic matter with nitrogen additions in two tropical forests. Ecology 92: $621-632$

Cusack DF, Silver WL, Torn MS, McDowell WH (2011b) Effects of nitrogen additions on above- and belowground carbon dynamics in two tropical forests. Biogeochemistry 104:203-225

Danger M, Daufresne T, Lucas F, Pissard S, Lacroix G (2008) Does Liebig's law of the minimum scale up from species to communities? Oikos 117:1741-1751

de Ruiter PC, Moore JC, Zwart KB, Bouwman LA, Hassink J, Bloem J, Devos JA, Marinissen JCY, Didden WAM, Lebbink G, Brussaard L (1993) Simulation of nitrogen mineralization in the belowground food webs of 2 winter-wheat fields. J Appl Ecol 30:95-106

Elser JJ, Andersen T, Baron JS, Bergstrom AK, Jansson M, Kyle M, Nydick KR, Steger L, Hessen DO (2009) Shifts in lake N:P stoichiometry and nutrient limitation driven by atmospheric nitrogen deposition. Science 326:835-837

Fanin N, Barantal S, Fromin N, Schimann H, Schevin P, Hattenschwiler S (2012) Distinct microbial limitations in litter and underlying soil revealed by carbon and nutrient fertilization in a tropical rainforest. PLoS One 7:e49990

Fanin N, Hättenschwiler S, Schimann H, Fromin N (2015) Interactive effects of $\mathrm{C}, \mathrm{N}$ and $\mathrm{P}$ fertilization on soil microbial community structure and function in an Amazonian rain forest. Funct Ecol 29: $140-150$

Feeley KJ, Silman MR, Bush MB, Farfan W, Cabrera KG, Malhi Y, Meir P, Revilla NS, Quisiyupanqui MNR, Saatchi S (2011) Upslope migration of Andean trees. J Biogeogr 38:783-791

Fierer N (2017) Embracing the unknown: disentangling the complexities of the soil microbiome. Nat Rev Microbiol 15:579-590

Fisher JB, Malhi Y, Torres IC, Metcalfe DB, van de Weg MJ, Meir P, Silva-Espejo JE, Huasco WH (2013) Nutrient limitation in rainforests and cloud forests along a 3,000-m elevation gradient in the Peruvian Andes. Oecologia 172:889-902

Frostegård A, Bååth E (1993) Shifts in the structure of soil microbial communities in limed forests as revealed by phospholipid fatty acid analysis. Soil Biol Biochem 25:723-730

Frostegård A, Tunlid A, Bååth E (2011) Use and misuse of PLFA measurements in soils. Soil Biol Biochem 43:1621-1625

Girardin CAJ, Malhi Y, Aragao LEOC, Mamani M, Huaraca Huasco W, Durand L, Feeley KJ, Rapp J, Silva-Espejo JE, Silman M, Salinas N, Whittaker RJ (2010) Net primary productivity allocation and cycling of carbon along a tropical forest elevational transect in the Peruvian Andes. Glob Chang Biol 16:3176-3192

Güsewell S, Gessner MO (2009) N:P ratios influence litter decomposition and colonization by fungi and bacteria in microcosms. Funct Ecol 23:211-219

Henriksen TM, Breland TA (1999) Nitrogen availability effects on carbon mineralization, fungal and bacterial growth, and enzyme activities during decomposition of wheat straw in soil. Soil Biol Biochem 31: $1121-1134$ 
Kamble PN, Bååth E (2014) Induced N-limitation of bacterial growth in soil: effect of carbon loading and N status in soil. Soil Biol Biochem 74:11-20

Kaspari M, Garcia MN, Harms KE, Santana M, Wright SJ, Yavitt JB (2008) Multiple nutrients limit litterfall and decomposition in a tropical forest. Ecol Lett 11:35-43

Kaspari M, Yanoviak SP, Dudley R, Yuan M, Clay NA (2009) Sodium shortage as a constraint on the carbon cycle in an inland tropical rainforest. P Natl Acad Sci USA 106:19405-19409

Kaspari M, Clay NA, Donoso DA, Yanoviak SP (2014) Sodium fertilization increases termites and enhances decomposition in an Amazonian forest. Ecology 95:795-800

Kirchman DL (2008) Microbial ecology of the oceans. Wiley, UK

Lednická D, Mergaert J, Cnockaert MC, Swings J (2000) Isolation and identification of cellulolytic bacteria involved in the degradation of natural cellulosic fibres. Syst Appl Microbiol 23:292-299

Malhi Y, Amezquita FF, Doughty CE, Silva-Espejo JE, Girardin CAJ, Metcalfe DB, Aragao LEOC, Huaraca-Quispe LP, Alzamora-Taype I, Eguiluz-Mora L, Marthews TR, Halladay K, Quesada CA, Robertson AL, Fisher JB, Zaragoza-Castells J, Rojas-Villagra CM, Pelaez-Tapia Y, Salinas N, Meir P, Phillips OL (2014) The productivity, metabolism and carbon cycle of two lowland tropical forest plots in south-western Amazonia, Peru. Plant Ecol Divers 7:85-105

Meidute S, Demoling F, Bååth E (2008) Antagonistic and synergistic effects of fungal and bacterial growth in soil after adding different carbon and nitrogen sources. Soil Biol Biochem 40:2334-2343

Minnikin DE, Collins MD, Goodfellow M (1979) Fatty-acid and polar lipid-composition in the classification of Cellulomonas, Oerskovia and related taxa. J Appl Bacteriol 47:87-95

Nottingham AT, Turner BL, Whitaker J, Ostle NJ, McNamara NP, Bardget RD, Salinas N, Meir P (2015a) Soil microbial nutrient constraints along a tropical forest elevation gradient: a belowground test of a biogeochemical paradigm. Biogeosciences 12:6071-6608

Nottingham AT, Whitaker J, Turner BL, Salinas N, Zimmermann M, Malhi Y, Meir P (2015b) Climate warming and soil carbon in tropical forests: insights from an elevation gradient in the Peruvian Andes. Bioscience 65:906-921

Pathan SI, Ceccherini MT, Hansen MA, Giagnoni L, Ascher J, Arenella M, Sorensen SJ, Pietramellara G, Nannipieri P, Renella G (2015) Maize lines with different nitrogen use efficiency select bacterial communities with different beta-glucosidase-encoding genes and glucosidase activity in the rhizosphere. Biol Fert Soils 51:995-1004

Quesada CA, Lloyd J, Schwarz M, Patiño S, Baker TR, Czimczik C, Fyllas NM, Martinelli L, Nardoto GB, Schmerler J, Santos AJB, Hodnett MG, Herrera R, Luizão FJ, Arneth A, Lloyd G, Dezzeo N, Hilke I, Kuhlmann I, Raessler M, Brand WA, Geilmann H, Moraes Filho JO, Carvalho FP, Araujo Filho RN, Chaves JE, Cruz OF Jr, Pimentel TP, Paiva R (2010) Variations in chemical and physical properties of Amazon forest soils in relation to their genesis. Biogeosciences 7:1515-1541

Rapp JM, Silman MR (2012) Diurnal, seasonal, and altitudinal trends in microclimate across a tropical montane cloud forest. Clim Res 55: $17-32$

Rousk J, Bååth E (2007) Fungal and bacterial growth in soil with plant materials of different $\mathrm{C} / \mathrm{N}$ ratios. FEMS Microbiol Ecol 62:258-267

Rousk J, Brookes PC, Bååth E (2009) Contrasting soil pH effects on fungal and bacterial growth suggest functional redundancy in carbon mineralization. Appl Environ Microb 75:1589-1596

Rousk J, Bååth E, Brookes PC, Lauber CL, Lozupone C, Caporaso JG, Knight R, Fierer N (2010) Soil bacterial and fungal communities across a $\mathrm{pH}$ gradient in an arable soil. ISME J 4:1340-1351

Six J, Frey SD, Thiet RK, Batten KM (2006) Bacterial and fungal contributions to carbon sequestration in agroecosystems. Soil Sci Soc Am J 70:555-569
Sterner RW, Elser JJ (2002) Ecological stoichiometry: the biology of elements from molecules to biosphere. Princeton University Press, Princeton

Strickland MS, Rousk J (2010) Considering fungal:bacterial dominance in soils - methods, controls, and ecosystem implications. Soil Biol Biochem 42:1385-1395

Tanner EVJ, Kapos V, Franco W (1992) Nitrogen and phosphorus fertilization effects on Venezuelan montane forest trunk growth and litterfall. Ecology 73:78-86

Teh YA, Diem T, Jones S, Huaraca Quispe LP, Baggs EM, Morley N, Richards M, Smith P, Meir P (2013) Methane and nitrous oxide fluxes from the tropical Andes. Biogeosciences 10:17397-17438

Traunspurger W, Reiff N, Krashevska V, Majdi N, Scheu S (2017) Diversity and distribution of soil micro-invertebrates across an altitudinal gradient in a tropical montane rainforest of Ecuador, with focus on free-living nematodes. Pedobiologia 62:28-35

Turner BL, Wright SJ (2014) The response of microbial biomass and hydrolytic enzymes to a decade of nitrogen, phosphorus, and potassium addition in a lowland tropical rain forest. Biogeochemistry 117:115-130

van de Weg MJ, Meir P, Grace J, Atkin OK (2009) Altitudinal variation in leaf mass per unit area, leaf tissue density and foliar nitrogen and phosphorus content along an Amazon-Andes gradient in Peru. Plant Ecol Divers 2:243-254

van de Weg MJ, Meir P, Williams M, Girardin C, Malhi Y, Silva-Espejo J, Grace J (2014) Gross primary productivity of a high elevation tropical montane cloud forest. Ecosystems 17:751-764

Vitousek PM (1984) Litterfall, nutrient cycling, and nutrient limitation in tropical forests. Ecology 65:285-298

von Liebig J (1855) Die Grundsatze der Agricultur-Chemie mit RuckSprengel, C. 1832. Chemie fur Landwirthe, Forstmanner und Cameralissicht auf die in England angestellten Untersuchungen (in England: ten (Chemistry for agronomists, foresters, and agricultural economy relations of chemistry to agriculture and the agricultural experimists). Vandenhoeck und Ruprecht Publ. Co.

Walker TW, Syers JK (1976) Fate of phosphorus during pedogenesis. Geoderma 15:1-19

Waring BG (2012) A meta-analysis of climatic and chemical controls on leaf litter decay rates in tropical forests. Ecosystems 15:999-1009

Whitaker J, Ostle N, Nottingham AT, Ccahuana A, Salinas N, Bardgett RD, Meir P, McNamara NP (2014) Microbial community composition explains soil respiration responses to changing carbon inputs along an Andes-to-Amazon elevation gradient. J Ecol 102:1058-1071

Wolf K, Veldkamp E, Homeier J, Martinson GO (2011) Nitrogen availability links forest productivity, soil nitrous oxide and nitric oxide fluxes of a tropical montane forest in southern Ecuador. Glob Biogeochem Cycles 25:GB4009

Zechmeister-Boltenstern S, Keiblinger KM, Mooshammer M, Peñuelas J, Richter A, Sardans J, Wanek W (2015) The application of ecological stoichiometry to plant-microbial-soil organic matter transformations. Ecol Monogr 85:133-155

Zhou ZH, Wang CK, Jin Y (2017) Stoichiometric responses of soil microflora to nutrient additions for two temperate forest soils. Biol Fert Soils 53:397-406

Zimmermann M, Meir P, Bird MI, Malhi Y, Ccahuana AJQ (2009) Climate dependence of heterotrophic soil respiration from a soiltranslocation experiment along a $3000 \mathrm{~m}$ tropical forest altitudinal gradient. Eur J Soil Sci 60:895-906

Zimmermann M, Meir P, Bird MI, Malhi Y, Ccahuana AJQ (2010) Temporal variation and climate dependence of soil respiration and its components along a $3000 \mathrm{~m}$ altitudinal tropical forest gradient. Glob Biogeochem Cycles 24:GB4012 